\title{
Responsabilidade Civil e Contratos de Locação Predial Urbana
}

\section{Marcelo Sampaio Siqueira}

Mestre em Direito pela Universidade Federal do Ceará(UFC). Doutorando em Direito Constitucional pela Universidade de Fortaleza (Unifor). Professor da Faculdade 7 de Setembro (FA7). msiqueira@siqueiraibiapina.com.br

Sumário: Introdução. 1. O direito de propriedade e o direito de locação. 2. A responsabilidade patrimonial. 3. O contrato de locação predial urbana. 4. O dever de reparar nas relações locacionais. Conclusão. Referências.

Resumo: $\mathrm{O}$ artigo trata da responsabilidade patrimonial advinda do inadimplemento das prestações originárias da relação locacional de imóvel urbano. Constituiu tarefa do artigo classificar o tipo de responsabilidade decorrente e analisar as prestações de natureza principal e acessória assumidas pelo locador e pelo locatário, cujo inadimplemento gera como consequência o dever de reparar.

Palavras-chave: Contrato. Responsabilidade patrimonial. Locação de imóvel urbano.

\section{NTRODUÇÃO}

Este artigo trata das relações existentes entre locadores e locatários derivado de contrato de locação regulado pela Lei 8.245/91, modificada pela Lei 12.112 de 09 de dezembro de 2009.

O contrato de locação, que tem natureza bilateral, como fonte de obrigações, estabelece prestações que devem ser observadas pelas partes, sob pena de restar caracterizada a falta de pagamento, constituindo um ato ilícito.

Não se configura pretensão mencionar todas as prestações cabíveis às partes envolvidas na relação, mas procurar caracterizar que o inadimplemento das prestações assumidas constituem uma responsabilidade contratual, que pode ser, em certos casos, até de natureza objetiva. 
O trabalho foi dividido nos seguintes tópicos: o direito de propriedade e o direito de locação; a responsabilidade patrimonial; o contrato de locação predial urbano e, por último, o dever de reparar na relação locacional.

\title{
10 DIREITO DE PROPRIEDADE E O DIREITO DE LOCAÇÃO
}

A propriedade é uma convenção humana e pode ser definida como o poder que o indivíduo ostenta sobre uma coisa estando presentes faculdades de usar, gozar, dispor e reivindicar, não sendo essas exaustivas ou absolutas, podendo inclusive alguns dos poderes estarem momentaneamente dissociados. No dizer de Ascensão:

\begin{abstract}
A propriedade concede a universalidade dos poderes que se podem referir à coisa. Por isso o proprietário tem vocação para o gozo. Este pode em concreto faltar, sem que em nada se toque a essência do direito. A propriedade fica então reduzida a um elemento qualitativo a que podemos também nos chamar casco ou raiz; mas como os poderes foram concedidos como universalidade, eles automaticamente se expandem quando a restrição desaparecer. Nisto consiste a elasticidade (2000, p.449).
\end{abstract}

De início, afirma-se por questão didática que propriedade não é um direito, sendo a sua proteção o direito (FIGUEIREDO, 2008, p. 50-51). Na verdade, o objeto de estudo deste item não é propriamente a propriedade em si, mas o direito de propriedade e as relações do seu detentor com a coisa imóvel.

A propriedade, além de não ser um direito também não pode ser caracterizada como um privilégio. Este termo sempre indica um direito exclusivo de poucos, já os poderes sobre a coisa, cuja proteção é um direito, é extensivo a qualquer cidadão, sendo protegida pelo Estado, desde que sejam respeitados certos condicionantes e limites.

O fato de poder usar, gozar, dispor e reivindicar exalta o poder do indivíduo sobre uma coisa, e o cerceamento pleno da propriedade leva de certa forma à extinção da própria liberdade, já que o direito à propriedade constitui um elemento clássico da autonomia privada do particular. Na lição de Richard Pipes, extrai-se que a ideia de liberdade e propriedade são interligadas (apud TORRES, 2008, p. 131). Mais adiante conclui: "Minha hipótese inicial dizia que há uma ligação íntima entre garantias públicas de propriedade e liberdade individual: que enquanto a propriedade de certa forma existe sem a liberdade, o contrário é inconcebível.”

Todo objeto passível de apropriação denota as faculdades citadas e o exercício destas constitui um indicativo de liberdade do dominador, embora, conforme será vistos nos itens que se sucedem, que o tipo de propriedade em estudo, fundiária, face a sua complexidade e a sua natureza de bem de produção, e não de consumo, sofra uma intensa intervenção estatal, objetivando, por mais paradoxal que seja, a concretização da liberdade atribuída ao proprietário sobre uma coisa. 
Ao se analisar a propriedade, deve-se delimitar que tipo de coisa é passível de apropriação e de gerar direito, um direito que é subjetivo absoluto no sentido de que não necessita de nenhuma relação com outra pessoa para que seja exercitado ou oponível.

Qualquer aspecto relativo ao direito de propriedade não pode ser dissociado da função social. Este princípio do direito constitui uma mudança de paradigma: do aspecto individual para o coletivo, trouxe para os dias de hoje uma crescente constitucionalização do direito privado (CANARIS, 2006, p. 20), devendo a legislação civil se adequar aos princípios consagrados.

O direito de locar o bem é uma das faculdades do direito de propriedade, já que o proprietário estaria utilizando-se da possibilidade de gozar o bem, ao destinar o imóvel a outra pessoa, que passaria a ter a posse direta, mediante pagamento de retribuição mensal, o que constituiria uma exploração econômica do proprietário, que extrairia frutos da coisa.

Preliminarmente expõe-se que o uso e o gozo, como não poderia deixar de ser, devem obedecer à função social, e o não cumprimento implica no desvirtuamento da propriedade e até na possibilidade de responsabilização do proprietário, que, via de regra, é o locador.

\section{ARESPONSABILIDADE PATRIMONIAL}

Apesar de no primeiro tópico ter-se tratado de um assunto relativo ao direito real, ou seja, a propriedade e a posse, o tema do artigo é relativo ao direito pessoal, pois trata da prática de ilícitos originários de uma relação locacional, que concede a posse do bem ao locatário, mediante uma prestação.

Não resta dúvida de que a relação jurídica oriunda de um contrato de locação pode acarretar responsabilidade civil, sendo importante em um primeiro momento conhecer acerca da responsabilidade ${ }^{1}$.

A importância do estudo da responsabilidade patrimonial por atos danosos, intimamente relacionada com o instituto das obrigações, está no sentido da realização da ideia de justiça que ela enseja, constituindo um dos campos mais interessantes do Direito, cuja evolução jurídica acentuou-se nos dias atuais, com o advento do novo Código Civil.

Não há dúvida de que a responsabilidade patrimonial gera um direito pessoal, constituindo um tópico especial do direito das obrigações, pois nela encontram-se presentes os requisitos de uma relação obrigacional, como a existência de credor e

\footnotetext{
1 O termo responsabilidade patrimonial é mais adequado do que responsabilidade civil, pois a sanção pela prática do ato ilícito recairá sobre o patrimônio do infrator. Se o patrimônio deste for negativo, nada acarretará a este, a não ser que a reparação seja paga em prestação de serviço.
} 
devedor, sendo este último o responsável por uma prestação, que possui relevância econômica, num determinado espaço de tempo. A especificidade está na fonte dessa obrigação, que é derivada de um ato ou omissão ilícitos ou da própria norma jurídica, que determina o dever de reparar, independentemente do elemento culpa ${ }^{2}$.

Responsabilidade patrimonial é a obrigação que uma pessoa, seja física ou jurídica, tem para o fim de restaurar o equilíbrio moral e patrimonial, de reparar o dano causado a outrem, por força de ação ou omissão ilícita ou por força da prescrição legal de ressarcir.

O fato ilícito ou o fato no qual a lei prescreve o dever de indenizar, de acordo com o conceito acima proposto, pode ser caracterizado como uma fonte de responsabilidades, as quais podem ser classificadas de duas formas: responsabilidade oriunda de ato culposo, artigo 186 do Código Civil, ou responsabilidade objetiva ou por resultado ${ }^{3}$.

A responsabilidade é uma medida de justiça, uma resposta a um determinado ato, sendo uma reação a um possível caso de enriquecimento ilícito, já que ela visa ao deslocamento do ônus do dano sofrido pelo lesado para a pessoa causadora do dano por ato positivo ou negativo. A indenização deve ser prestada de tal forma que a vítima tenha seus danos ressarcidos, voltando a sua situação patrimonial de antes, não podendo também ser superior aos danos sofridos sob pena de se configurar um enriquecimento indevido e sem causa.

O tipo de responsabilidade em análise, ou seja, do locador, pode ser classificado como contratual, de que se pode extrair os seguintes elementos, seja qual for a teoria adotada (subjetiva ou do risco): a) existência de uma ação comissiva ou omissiva; b) ocorrência de um dano, que pode ser moral ou patrimonial; c) nexo de causalidade entre a ação e o dano.

O primeiro requisito é o ato humano, que pode ser comissivo ou omissivo, exteriorizando-se como um ato ilícito, teoria da culpa (responsabilidade subjetiva ou aquiliana $)^{4}$, ou teoria do risco (responsabilidade objetiva), assentado na previsão legal, que fundamenta a responsabilidade patrimonial.

2 Aqui encontramos a primeira inovação, já que o dever de reparar pelo ato ilícito não é tratado mais na parte geral, que apenas define o que é ato ilícito, artigo 186 do Código Civil vigente, e sim no título que trata da Responsabilidade Civil. Salienta-se também que o citado artigo 927 também traz expressamente em seu tipo a regra que determina a reparação em casos especificados em lei em conformidade com a natureza do risco e independentemente do elemento culpa.

3 Venosa, ao tratar da responsabilidade objetiva, conceitua que essa, como regra geral, leva-se em conta o dano, em detrimento do dolo ou da culpa (2003, p.18). Desse modo, para o dever de indenizar, bastam o dano e o nexo causal, prescindindo-se da prova da culpa.

4 A culpa, que pode ser representada pelo dolo ou pela culpa "stricto sensu", concerne no aspecto subjetivo da pessoa que praticou o ato, ao passo que a ilicitude tem em vista o valor objetivo do fato, isto 
O segundo elemento é a ocorrência de um dano, que pode ser material ou moral, que deve ser comprovado pela vítima, não podendo ser hipotético ou conjectural. $\mathrm{Na}$ lição de Lopes, para que haja dano relevante à ordem jurídica, "é preciso que haja um prejuízo decorrente da lesão de um direito" (1995, p. 222).

O dano é a consequência do ato, que deve ser ilícito, causando um passivo no patrimônio da vítima ou um abalo no seu bem-estar psíquico, patrimônio moral, não apreciável economicamente. Quando se fala em lesão de direito, englobam-se não só os bens materiais corpóreos e incorpóreos, mas também os bens personalíssimos, não passíveis de análise econômica.

A responsabilidade patrimonial só existirá caso haja um dano a reparar, desde que não exista qualquer excludente de responsabilidade. Conforme visto, o dano poderá ser material ou moral, podendo o ato causar os dois, gerando a obrigação de o agente responder patrimonialmente por ambos.

O material é representado pelos danos emergentes e pelos lucros cessantes. O primeiro configura-se na efetiva diminuição do patrimônio da vítima, e o segundo seria o que se deixou de ganhar. Este tipo de dano ocasiona diminuição efetiva no patrimônio físico do sucumbente.

Já o dano moral ${ }^{5}$ não tem como conseqüência a diminuição do patrimônio físico da pessoa. Ele é representado pelo dano causado ao íntimo da vítima, ao nome profissional e familiar, à honra, causando dor e acarretando uma lesão na estima que a pessoa possui de si própria.

A reparação do dano, seja qual for o tipo, pode ser representada por uma prestação pecuniária, responsabilidade patrimonial, que visa a restituir a situação ao status quo originário. O dano moral também é reparado da mesma forma, o que representa uma pena ao infrator e, embora a dor não tenha preço, a indenização pecuniária serve para compensar a violação ao seu direito, possibilitando atenuar o sofrimento, possibilitando diversões, objetivando a recuperação do equilíbrio psíquico abalado ${ }^{6}$.

é, o próprio ato que negou os valores tutelados pela norma jurídica, não se encontrando em análise se o ato foi em consequência de qual aspecto subjetivo. Em síntese, o ilícito é o ato, a culpa é o elemento volitivo ou negligencial causador do ato e que em certos casos previstos em lei poderá não está presente (responsabilidade por resultado ou objetiva).

5 "O fundamento da responsabilidade pelo dano moral está em que, a par do patrimônio em sentido técnico, o indivíduo é titular de direitos integrantes de sua personalidade, não podendo conformar-se à ordem jurídica em que sejam impunemente atingidos.” (PEREIRA, 1996, p.54).

${ }^{6}$ Vide súmula 37 do STJ: "São cumuláveis as indenizações por dano material e dano moral oriundos do mesmo fato." 
Existem certas situações em que, embora os atos gerem danos, não se caracteriza a responsabilidade patrimonial, que pode ser afastada pela inexistência da relação de causalidade $^{7}$ ou por causas excludentes de responsabilidade, isto é, se o ato causador for originário de caso fortuito, força maior ou culpa exclusiva da vítima ${ }^{8}$.

O terceiro elemento é o nexo de causalidade entre o ato e o dano. Se não existir este elo não cabe responsabilidade patrimonial, seja a contratual, seja a extracontratual, isto é, se o ato praticado pelo agente não foi o responsável pelo dano sofrido, não há como prosperar o pedido de reparação do dano.

No tema em questão, o objeto de análise é o contrato de locação predial urbana e as conseqüências advindas da prática de ato ilícito durante a relação locacional. O conhecimento dos elementos constitutivos da responsabilidade, desenvolvidos neste tópico, é essencial às conclusões a serem desenvolvidas quando da apresentação dos fatos jurídicos geradores ou não do dever de reparar.

\section{CONTRATO DE LOCAÇÃO PREDIAL URBANA}

A relação jurídica advinda da locação é complexa, pois envolve a concessão da posse, que se constitui um direito real, embora que o contrato estabelece prestações às partes, que é de natureza pessoal ${ }^{9}$.

O direito de locação, que tem por base uma relação obrigacional, pode ser classificada como um direito pessoal de gozo e não um direito real de gozo, cujo exemplo seria o usufruto.

\footnotetext{
7 Relação de causalidade, segundo Carlos Alberto Gonçalves: É a relação de causa e efeito entre a ação ou omissão do agente e o dano verificado. Vem expressa no verbo "causar", utilizado no artigo 159. Sem ela, não existe a obrigação de indenizar. Se houve o dano mas sua causa não está relacionada com o comportamento do agente, inexiste a relação de causalidade e também a obrigação de indenizar. Se, verbi gratia, o motorista está dirigindo corretamente e a vítima, querendo suicidar-se, atira-se sob as rodas do veículo, não se pode afirmar ter ele "causado" o acidente, pois na verdade foi um mero instrumento da vontade da vítima, esta sim responsável exclusiva pelo evento. (2003, p. 33).

${ }^{8}$ Há ainda as causas excludentes de culpabilidade que são: a menoridade, a perturbação mental, consentimento da vítima; exercício normal de um direito, legítima defesa, estado de necessidade e a prescrição. Salienta-se que a culpa da vítima, culpa de ambos, culpa de terceiro e a existência de força maior constituem excludentes do nexo causal.

9 Citando Mesquita, conclui-se que a obrigação vista pelo ativo é o direito que permite exigir uma prestação a determinada pessoa; o jus in re, por sua vez, é o direito que incide diretamente sobre uma coisa, sem a mediação de quem quer que seja (2000, p. 51). Mais adiante, o mesmo autor leciona que o direito real foi definido como o poder conferido ao respectivo titular de excluir todas as demais pessoas de qualquer ingerência na coisa que constitui o seu objeto, sempre que essa ingerência seja incompatível com o conteúdo do direito. Ao final expõe: Direitos reais são estruturalmente relações entre pessoas, funcionalmente são direitos que colocam uma coisa à disposição do respectivo titular;
} 
A explicação para a classificação acima está no fato de que, segundo Ascensão, o direito real é um direito absoluto no sentido de que sua existência não depende de uma relação prévia entre as partes, já o direito relativo, como por exemplo o pessoal, é o que assenta numa relação (2000, p.45). Os titulares de direitos citados em primeiro lugar, que não se assentam em relação nenhuma, têm uma posição absoluta, porque são garantidos pela ordem jurídica, independentemente de qualquer relação particular ${ }^{10}$.

O contrato de locação estabelece inúmeras prestações para as partes envolvidas, sendo importante também apresentar especificação para as prestações devidas. O locador, como ocupante de um dos pólos da relação obrigacional, tem como deveres contratuais ou legais básicos: a) dar a posse direta do bem ao locatário; b) fazer com que a locação sirva para o fim a quê se destina. Como se constitui uma relação bilateral atributiva, o locatário possui também deveres principais, que são: a) dar o valor referente ao aluguel mensal convencionado; b) restituir (prestação de dar) o imóvel ao término da locação, entre outras.

No entanto, duas questões de natureza regulamentar ganham relevância ao tratarmos do contrato de locação. Primeira, o Código Civil de 2002, em eu artigo 2.036, fixa expressamente a eficácia de lei especial, que no presente caso é a 8.245/91, para regular a locação de prédio urbano. Segunda, o alcance do CDC no concernente às relações locacionais.

Não há dúvida de que o Código Civil de 2002, ao tratar no capítulo da locação, só está a regular os contratos de locação fora do alcance da Lei especial, como por exemplo os contratos de locação de bens móveis; de bens imóveis pertencentes à entidade da administração direta ou indireta, desde que não exista legislação específica; vagas autônomas de garagem, entre outros exemplos expressos no artigo $1^{\circ}$. da Lei 8245/91.

Não se poderia deixar de afirmar que os princípios gerais dos contratos determinados pelo Código novo são aplicáveis ao contrato de locação de prédio urbano regulado pela lei especial, já que a norma geral aplicar-se-ia subsidiariamente.

A questão atinente à aplicação do Código de defesa do consumidor é mais prolixa. Venosa conclui que "o ordenamento consumerista será aplicado naquilo que completar e se harmonizar com o espírito não só da lei inquilinária como de tantos outros diplomas legais." (2007, p. 28).

O ponto nodal para equacionar o questionamento lançado é responder se a relação obrigacional criada pelo contrato de locação é de consumo.

Defendemos a posição de que a relação será de consumo se o locatário puder ser definido como consumidor e se o locador for um fornecedor. Mas o tópico central

\footnotetext{
${ }^{10}$ exemplificando: num litígio envolvendo um direito de propriedade do imóvel o proprietário só tem que demonstrar sua propriedade, é o que basta para exigir a entrega da coisa, não tendo que tratar dos atos jurídicos.
} 
seria concluir se a locação é ou não uma prestação de serviço. Logo, discordamos do entendimento de que basta a conceituação de consumidor na relação jurídica para a aplicação da norma consumerista, a relação ex locato, sem a preocupação de tipificar a figura do fornecedor.

Ao analisarmos a figura do locatário e as condições às quais tem direito, pode-se dizer que este seria um consumidor ${ }^{11}$. Mas será que o locador seria um fornecedor?

O artigo 3o. da Lei 8.078/90 diz que fornecedor é aquele que desenvolve atividades de produção e transformação em geral ou que presta serviço. Mas será que o locador desenvolve uma prestação de serviço?

A prestação de serviço segundo a ciência econômica é um conceito fluido, não tão claro quanto o conceito de produção de um bem ${ }^{12}$. Pode-se dizer que se constitui a realização de uma atividade que objetiva a produção de um trabalho contratado por terceiros, a qual pode ser remunerado e ter natureza corpórea ou incorpórea.

Analisando-se esse conceito, afirma-se que nem sempre o locador pode ser caracterizado como um prestador de serviço perante o locatário ${ }^{12}$. Vai depender da pessoa do locador.

Em nosso entendimento, quando o locador de bem imóvel urbano for pessoa natural ou jurídica, ou qualquer ente despersonalizado sujeito de direitos e deveres, como por exemplo: o espólio, que não tenha como atividade fim a locação de imóvel, não se pode afirmar se o locador é um fornecedor, pois não está a prestar serviço. Logo, nessa relação não se aplicariam as normas do Código de Defesa do Consumidor, mas somente a Lei das Locações e do Código Civil no tocante aos princípios gerais dos contratos ${ }^{13}$.

\footnotetext{
${ }^{11}$ vide artigo $2^{\circ}$. da Lei 8245/91.

${ }^{12}$ Sobre a teoria da produção e serviço vide a obra de C.E. Ferguson (1991).

${ }^{13}$ Ementa: AGRAVO REGIMENTAL EM RECURSO ESPECIAL. LOGAÇÃO. GONTRATO POR PRAZO DETERMINADO. FIANÇA. CLÁUSULA QUE A PRORROGA ATÉ A ENTREGA DAS CHAVES. POSSIBILIDADE. ANUÊNCIA EXPRESSA DO FIADOR. SÚMULA 214/STJ. INAPLICABILIDADE. PRECEDENTES. APLICAÇÃO DO CÓDIGO DE DEFESA DO CONSUMIDOR ÀS RELAÇÕES LOCATÍCIAS DISCIPLINADAS PELA LEI 8.245/91.IMPOSSIBILIDADE.1. A $3^{\text {a }}$ Seção deste Tribunal, no julgamento do REsp 566.633/CE,rel. Min. Paulo Medina, assentou a validade de cláusula de contrato de locação por prazo certo que prorrogue a fiança até a entrega das chaves do imóvel, se expressamente aceita pelo fiador que não se exonerou do encargo na forma do art. 835 do Diploma Civil atual, correspondente ao art. 1.500 do Código Civil de 1916; 2. A controvérsia em análise não contempla hipótese de aditamento ao contrato de locação, razão por que não se aplica ao caso a Súmula 214/STJ. 3. Esta Corte possui orientação pacífica no sentido de que as normas do Código de Defesa do Consumidor (Lei 8.078/90) não se aplicam às relações locatícias disciplinadas pela Lei 8.245/91. 4. Agravo regimental improvido. (STJ. AgRg no REsp 922763 / RS, Relatora Ministra Maria Thereza de Assis Moura, Sexta turma, Data da publicação 19.12.2007, pp.1253)
} 
Contudo, quando o locador for uma pessoa natural ou jurídica que desenvolva a atividade de corretagem (administração de imóveis), não resta dúvida de que se estaria diante de uma prestação de serviço, sujeitando-se o contrato de locação, firmado pela prestadora, às regras da Lei 8.078/90 $0^{14}$.

\section{DEVER DE REPARAR NAS RELAÇÕES LOCACIONAIS}

A relação locacional, conforme o visto, é derivada de um contrato do qual acarretam direitos e deveres às partes envolvidas, sendo que o não cumprimento desses gera consequências.

Preliminarmente, após o estudo da responsabilidade patrimonial e do contrato de locação, afirma-se que o inadimplemento de uma prestação, cuja fonte seria o citado termo, caracteriza a responsabilidade contratual, pois existe uma relação anterior entre o credor e o devedor.

A caracterização apresentada é essencial para delimitar-se a matéria, pois o Código Civil de 2002, seguindo a doutrina tradicional dualista, trata em disciplinas diversas a responsabilidade contratual da extracontratual ou aquiliana.

A primeira estaria regulamentada na parte geral das obrigações, como uma consequência do não cumprimento da prestação ${ }^{15}$. Já a responsabilidade contratual seria tipificada pelos artigos 186 a 188, 927 e seguintes $^{16}$.

É fato que há diferenças entre essas duas espécies de responsabilidade, mas é incontestável que as mesmas possuem os mesmos requisitos: ato ou omissão ilícito; nexo de causalidade e dano.

O inadimplemento de uma prestação oriunda de um contrato não deixa de ser um ato ilícito, sendo que na responsabilidade contratual, ao contrário da aquiliana, a vítima, que é a credora da reparação, só precisa provar a falta do pagamento ${ }^{17}$. A questão da culpa ou de sua inexistência constitui elemento probandi do infrator, que só escapa do dever de reparar se provar que não teve culpa, o que se caracteriza uma excludente de culpabilidade.

\footnotetext{
${ }^{14}$ Ementa: PROGESSO GIVIL - AÇÃO GIVIL PÚBLICA - LOCAÇÃO - CLÁUSULAS ABUSIVASADMINISTRADORAS DE IMÓVEIS- LEGITIMIDADE PASSIVA AD CAUSAM -INTERESSES INDIVIDUAIS HOMOGÊNEOS.As administradoras de imóveis são legitimadas para figurarem no pólo passivo em ações civis coletivas propostas pelo Ministério Público com objetivo de declarar nulidade e modificação de cláusulas abusivas, contidas em contratos de locação elaboradas por aquelas. (Precedentes). Recurso Especial provido. (STJ. REsp 614981/Mg, Relator Ministro Felix Fischer, Quinta turma, Data da publicação 26.09.2005, pp.439)

${ }^{15}$ Artigos 389 e 395, ambos do Código Civil de 2002.

${ }^{16}$ Sobre essa teoria ver Carlos Alberto Gonçalves (2003, p.26-27).

${ }^{17}$ Que nesse caso significa cumprimento de prestação.
} 
O objetivo deste artigo se propõe a responder que atos ilícitos podem advir da relação locacional de imóvel urbano e quais as consequências destas práticas.

Não é pretensão do trabalho, em poucas linhas, esgotar as possibilidades acerca dos atos passíveis de gerar direito à reparação numa relação locacional, pois seria inviável face às inúmeras prestações imputáveis a cada parte. O intuito é destacar os fatos mais comuns e falar da reparação cabível e possível.

A reparação na responsabilidade contratual, segundo o artigo 389 do Código Civil, seria o pagamento das perdas e danos, mais juros e atualização monetária segundo índices oficiais regularmente estabelecidos e honorários de advogado. Pode-se ainda acrescentar a esse rol a multa contratual, seja ela compensatória ou moratória, estabelecida nos artigos 408 e seguintes do diploma civil vigente.

Nem sempre os contratos trazem a estipulação de cláusulas penais, que nada mais é que a pré-fixação das perdas e danos pelas próprias partes ${ }^{18}$. Nesses casos a reparação ficaria adstrita às penas impostas pelo citado artigo 389 do Código Civil, sem esquecer-se a necessidade do inadimplemento acarretar dano ${ }^{19}$.

Traçadas essas considerações acerca das consequências pelo descumprimento da prestação, passa-se a análise dos fatos jurídicos que caracterizariam atos ilícitos na relação locacional, considerando-se serem as partes legítimas para a realização do contrato. Para facilitar a didática, passa-se a dividir os fatos em dois grupos: fatos imputáveis ao locador e fatos imputáveis ao locatário.

\subsection{FATO IMPUTÁVEL AO LOCADOR}

O artigo 22 da Lei 8245/91 estabelece inúmeros deveres ao locador, cujo descumprimento torna o ato inválido e passível de reparação independentemente de previsão contratual. Um dos mais importantes deveres seria a concessão da posse do bem em estado de servir ao uso que se destina. O inquilino ao alugar o bem imóvel tem um objetivo já prefixado no contrato e o seu não atendimento pode gerar a responsabilização do locador. Imagina-se: a locação de uma casa residencial que não atenda as condições de habitabilidade ou a locação de um imóvel para fins não residenciais, cujo ordenamento do Município não permita a exploração de comércio para o local ${ }^{20}$.

\footnotetext{
${ }^{18}$ Lembra-se, no entanto, que a cláusula penal tem duas funções: compulsória e indenizatória. A que estamos tratando nesse parágrafo é a indenizatória.

${ }^{19}$ Observa-se que é devido o pagamento da multa contratual estabelecida em caso de inadimplência independentemente da existência de dano.

${ }^{20}$ Sobre essa questão da imprestabilidade do imóvel ver decisões: TJCE - Ap 98.03331-0 e TJRJ 2008.001.01640.
} 
Outro exemplo que se pode destacar é a locação de imóvel que, embora tenha condições técnicas de habitação, não teve licença deferida para sua construção pela edilidade, caracterizando a existência de um imóvel irregular. Nesse caso, o bem locado não serve para o fim almejado, o que acarreta a existência de ilícito e dever de reparar ao inquilino, que não poderá usar a coisa.

No tocante ao dever de garantir o uso pacífico do bem, pode-se citar que ao locador é vedado alugar bem sob o qual exista ordem judicial definitiva que lhe retire a posse ou a titulariedade. Ocorrendo isso, o locatário poderá vir a ter problemas com a ordem de se retirar do imóvel, o que lhe proporcionaria o direito de requerer perdas e danos ${ }^{21}$.

É interessante ressaltar que fato superveniente à locação, como, por exemplo, um raio que afete a parte elétrica de uma loja comercial, acarretando a necessidade de troca de fiação, faz com que o locador tenha o dever de consertar a parte elétrica, pois casa sem energia elétrica compromete o destino do imóvel. O não cumprimento implica no dever de reparar patrimonialmente.

A responsabilidade, no entanto, desaparece ou tem seus efeitos diminuídos caso o inquilino demore em notificar ao locador da existência do dano no imóvel.

Vale salientar que a locação de imóvel com defeito já conhecido pelo locador implica não só o direito do inquilino requerer a rescisão contratual, mas até a cobrança de perdas e danos, face o defeito e o desrespeito ao princípio da boa-fé objetiva.

Os últimos quatro parágrafos trouxeram tipos descritos no artigo 22 da lei 8245/91, mas se podem destacar outros deveres imputáveis ao devedor, cujo inadimplemento acarretaria o direito ao locatário requerer perdas e danos. Nesse caso, em conformidade com o artigo 33 da Lei 8245/91, cita-se em primeiro lugar o fato de que a não concessão de preferência ao locatário para aquisição do bem locado, nas mesmas condições obtidas por terceiro adquirente, implica no pagamento das perdas e danos, sendo esse tipo de responsabilidade do tipo objetiva, pois é advinda da lei, não sendo necessário se perquirir sobre a culpa ${ }^{22}$. Ao locatário basta demonstrar que não lhe foi dada a preferência ${ }^{23}$.

\footnotetext{
${ }^{21}$ Segundo Maria Helena Diniz: O locador deverá, ainda, na hipótese de evicção, se agiu de má-fé, pagar as perdas e danos, por ter levado o inquilino a realizar contrato que não faria se soubesse da real situação dominial do prédio locado. Não há qualquer responsabilidade do locador por desapropriação ou requisição do imóvel locado, que decorrem do factum principis, ou seja, de ato de autoridade pública (2008, p.108).

${ }^{22}$ Sobre a questão da preferência ver o julgado JTACSP (Revista dos Tribunais 114:238), que defende a tese de que as perdas e danos pela não concessão do direito de preferência só é devida caso o preterido prove condições financeiras para adquirir o bem.

${ }^{23}$ Segundo o artigo 33 da Lei 8245/91, se o contrato de locação estiver averbado no Cartório de Registro competente pelo menos 30 dias antes da alienação junto a matrícula do imóvel, o inquilino possui o direito de depositando o preço e demais despesas do ato de transferência haver para si o imóvel alienado a terceiro.
} 
O artigo 52, parágrafo terceiro da Lei 8.245/91, estipula, em caso de perda do direito de renovação do contrato, direito do locatário à indenização para ressarcimento dos prejuízos e dos lucros cessantes que tiver que arcar com a mudança, perda do lugar e desvalorização do fundo de comércio, se a renovação não ocorrer em razão de proposta de terceiro, em melhores condições, ou se o locador, no prazo de três meses da entrega do imóvel, não der o destino alegado ou não iniciar as obras determinadas pelo Poder Público ou que declarou pretender realizar. Expõe-se que tal responsabilidade é objetiva ${ }^{24}$.

É importante mencionar que certos atos praticados pelo locador podem até acarretar responsabilidade penal, sendo, portanto, também um ilícito penal punível com prisão simples, prestação de serviço à comunidade ou multa de três a doze meses do valor do último aluguel atualizado, revertida em favor do locatário. Como exemplo disso, cita-se: a cobrança antecipada de aluguéis fora dos casos previstos em lei (locação por temporada); a cobrança de pagamento de quantia superior a devido a título de aluguéis e encargos; a exigência de mais de uma modalidade de garantia; não fornecimento de recibo discriminado do aluguel e encargos; não dar o destino indicado ao bem, no prazo fixado pela lei, quando o recupera para uso próprio ou para parentes indicados na regra ${ }^{25}$.

Logo, a responsabilidade do locador, em determinados atos, pode ser patrimonial e penal. Conclui-se também que a responsabilidade penal não exclui a patrimonial.

Resta claro que a infração de qualquer dos deveres citados no artigo 22 da Lei 8245/91, como também dos outros preceitos ora citados, gera como consequência não só o direito de reparar previsto no artigo 389 do Código Civil, mas também no direito do inquilino requerer a nulidade do ato jurídico ou da cláusula indevidamente estipulada em face do artigo 45 da Lei 8245/91, que proíbe a existência de estipulações que visem a elidir os objetivos da lei do inquilinato. Em certos casos, que denote o descumprimento da obrigação principal do contrato de locação, pode o inquilino até denunciar a locação sem arcar com o pagamento de multa contratual, caso o contrato esteja por prazo determinado, constituindo esse fato também uma pena.

\subsection{FATO IMPUTÁVEL AO LOCATÁRIO}

A relação locacional também impõe deveres ao locatário e o inadimplemento desses gera ao locador o direito de requerer reparação.

\footnotetext{
${ }^{24}$ Sobre ação renovatória e dever de reparar ver: Súmulas 181 e 444 do STF. Indica-se que nesses casos a norma do Dec.24.150/34 é semelhante a regra do artigo 52.

${ }^{25}$ Ver artigo 43 e 44 da Lei 8245/91, sendo que os três primeiros exemplos são de contravenção penal.
} 
Nesse aspecto destaca-se duas prestações principais imputadas ao inquilino ou sublocatário que seriam de pagar pontualmente o aluguel e encargos da locação e de restituir o bem ao término da locação no estado em que o recebeu, salvo as deteriorações decorrentes do seu uso normal, artigo 23, inciso I e III da Lei 8245/91.

O não pagamento dos aluguéis e encargos, por se tratar de prestação pecuniária, gera ao locador o direito de cobrar juros, sem prejuízo da cláusula penal porventura estipulada, atualização monetária e honorários de advogado, independentemente da comprovação de dano, face o preceito do artigo 404 do Código Civil.

Acerca do segundo tipo citado, restituição do imóvel, afirma-se que o locatário responderá não só pela demora na devolução do bem, caso não cumpra com seu dever, podendo a liquidação do dano ser determinada pelo pagamento de aluguel a preço de mercado do imóvel, durante o período que deveria ter entregue o bem e não o fez. Mas observa-se que a obrigação não é só de restituir o imóvel, pois este deve ser entregue ao locador no estado em que o recebeu, desconsiderando-se, no entanto, os desgastes sofridos pelo tempo acarretados pelo uso normal.

O fato do inquilino ter recebido o imóvel pintado, sem dúvida alguma o obriga a entregar o imóvel também pintado, não podendo dizer que as falhas na pintura são decorrentes do uso normal. A correta exegese do preceito do inciso III da Lei 8.235/91 estaria na proteção do inquilino de responder pelo desgaste natural do bem, que ocorreria mesmo que o bem não estivesse sendo utilizado, como, por exemplo, a oxidação das torneiras, no entanto, seria impossível ao inquilino usar a coisa, mesmo que de forma normal, sem que estragasse a pintura, o que acarretaria a ele o dever de pintar o bem ao restituí-lo. Observa-se que essa responsabilidade só existirá se o locatário tiver recebido o imóvel com pintura nova, devendo devolver o bem no mesmo estado.

Pode-se citar também, como ilícito praticado pelo inquilino, a utilização do imóvel para fim diverso do estabelecido no contrato (artigo 23, inciso II da Lei 8245/91). Locar casa para fins residenciais e explorá-la como bem comercial acarreta não só o direito ao locador requerer a rescisão contratual, artigo $9^{\circ}$. Inciso II da Lei 8245/91, mas a pedir perdas e danos pela infração.

Outro fato muito comum, infelizmente, é a mudança da forma interna ou externa do imóvel sem o consentimento prévio e por escrito do locador. São inúmeras as lides cujo fato é oriundo da mudança indevida das cores da fachada do imóvel pelo inquilino, sem a autorização do proprietário. Essa infração permite não só a rescisão contratual, mas o desfazimento da pintura às custas do infrator, sem prejuízo das perdas e danos ${ }^{26}$, artigo 251 do Código Civil.

\footnotetext{
${ }^{26}$ Neste caso a vítima vai observar a existência de danos emergentes, lucros cessantes ou danos morais.
} 
Uma das prestações exigíveis do locatário de um apartamento é que este respeite as normas do condomínio. A desobediência poderá levar o condomínio a multar pela infração cometida, sendo esta em última instância suportada pelo inquilino. No entanto, a cobrança direta da multa será efetuada ao locador (obrigação propter rem)27 que poderá ter o direito de regresso contra o inquilino e usar dos fatos para caracterizar infração contratual e requerer em ação apropriada a rescisão contratual ${ }^{28}$.

Por fim, observa-se que há certos atos praticados pelo locatário que caracterizariam uma responsabilidade objetiva. Entre esses, destaca-se a denúncia do contrato pelo locatário sem a concessão de aviso prévio não inferior a trinta dias. Complementa-se que a própria Lei do inquilinato, artigo $6^{\circ}$, determina a reparação, fixada no pagamento de um mês de aluguel e encargos, vigentes quando da resilição. Outro exemplo desse tipo ocorrerá quando o locatário devolver o imóvel antes do término do prazo contratual, artigo $4^{\circ}$ da Lei 8.245/91, modificado pela Lei 12.112/2009, sujeitando-se ao pagamento da multa pactuada proporcional ao período de cumprimento do contrato, ou na sua falta, que for judicialmente estipulada.

Questão interessante é analisar se o fiador, caso exista contrato de fiança garantindo a relação locacional, responde pelos atos ilícitos do afiançado. A resposta é positiva, pois a função do fiador é garantir ao credor a satisfação das obrigações assumidas pelo locatário caso esse não as cumpra. Alia-se a isso o fato de que o fiador, dependendo das estipulações, pode transformar-se em devedor principal ou solidário.

As modificações trazidas pela Lei 12.112 de 09 de dezembro de 2009 trazem importantes tipificações no tocante a responsabilidade do fiador no contrato de locação. Em primeiro lugar, pacifica o entendimento de que a responsabilidade do locador, salvo disposição contratual em contrário, se estende até a devolução do imóvel, mesmo que a locação esteja prorrogada por prazo indeterminado. Em segundo lugar, possibilita o fiador, quando o contrato estiver por prazo indeterminado, solicitar sua exoneração. Nesse caso, o fiador ficará responsável pela garantia pelo prazo de 120 (cento e vinte) dias, a contar da notificação ao locador, e a locação poderá ser desfeita caso o locatário não apresente outra garantia ${ }^{29}$.

Ressalta-se que outras prestações podem ser assumidas por locadores e locatários por força de estipulação contratual, sendo seu inadimplemento capaz de gerar as mesmas consequências aqui descritas. Como ilustração cita-se a cláusula que impede o locatário de ceder ou sublocar o imóvel, artigo 13 da Lei 8.245/91.

Faz-se necessário, após tratar-se dos fatos que podem ensejar ato ilícito e consequentemente o dever de reparar, tratar da liquidação do dano.

\footnotetext{
${ }^{27}$ Prestação derivada do domínio sobre a coisa. Exemplo: taxa de condomínio edilício; IPVA, entre outros.

${ }^{28}$ Ver $2^{\circ}$. TACSP, Ap. c/ Ver. 241.533.

${ }^{29}$ Vide artigos 39 e 40, inciso X, e seu parágrafo único da Lei 8245/91, modificado pela Lei 12.112/2009.
} 


\subsection{LIQUI DAÇÃO DO DANO}

$\mathrm{O}$ dano, que deve ser provado ${ }^{30}$, oriundo dos atos tratados nesse artigo será de natureza eminentemente patrimonial, sendo difícil que um dos atos tratados nesse artigo possam caracterizar dano moral. Lembra-se que a simples chateação não induz à ocorrência de dano moral ${ }^{31}$.

O título IX do Livro I, do Código Civil de 2002 trata da Responsabilidade Civil, e, segundo a sistemática do Código, se aplica a responsabilidade aquiliana. Entende-se, no entanto, que algumas regras do referido livro se aplicam também à responsabilidade contratual, servindo de subsídio para a liquidação das perdas e danos, como por exemplo a questão da gradação da culpa estabelecida no artigo 945 do referido diploma civil.

Caso as partes não promovam entendimento acerca do quantum a reparar, não resta outra alternativa que seja levar o caso ao judiciário para que esse fixe o valor da reparação. No caso em tela, sempre serão observados os itens do artigo 389 do Código Civil, combinados com as regras dos artigos 944 e seguintes.

\section{CONCLUSÃO}

A análise das conclusões obtidas com a pesquisa, que trata do questionamento acerca dos tipos que induzem o dever de reparar derivado da relação locacional urbana e exposta neste artigo ao longo dos itens dissertados, pode ser apresentada nos seguintes pontos:

1) $O$ direito de locação, que tem por base uma relação obrigacional, pode ser classificado como um direito pessoal de gozo e não um direito real de gozo, cujo exemplo seria o usufruto;

2) A relação locacional nem sempre pode ser caracterizada como uma relação de consumo. Logo, nesses casos não há que se falar em aplicação do Código de Defesa do Consumidor;

3) O artigo 389 do Código Civil traz o que será reparado quando se tratar de responsabilidade contratual;

4) A responsabilidade advinda de infração cometida na relação locacional urbana, tratada pela Lei 8245/91, não é apenas de natureza civil, podendo ser também de natureza penal;

\footnotetext{
${ }^{30}$ Sobre a questão da necessidade de se provar o dano ver: REsp 617989 / PB.

${ }^{31}$ Em relação ao assunto dano moral e aborrecimento, ver Carlos Alberto Gonçalves (2003, p. 548).
} 
5) Os artigos 22 e 23 da Lei 8245/91 trazem os deveres dos locadores e dos locatários, sem prejuízo da estipulação de outras prestações pelo contrato. O não cumprimento desses implica no dever de reparar e na possibilidade de se requerer a rescisão contratual.

\section{REFERÊNCIAS}

ASCENSÃO, José de Oliveira. Direito civil reais. 5. ed. Coimbra: Coimbra, 2000. CANARIS, Glaus - Wilhelm. Direitos fundamentais e direito privado. Trad. Ingo Wolfgang Sarlet e Paulo Mota Pinto. Lisboa: Almedina, 2006.

DINIZ, Maria Helena. Lei de locações de imóveis urbanos comentada. 9. ed. São Paulo: Saraiva, 2008.

FERGUSON, C.E. Microeconomia. 15. ed. Rio de Janeiro: Forense Universitária, 1991.

GONÇALVES, Carlos Roberto. Responsabilidade civil. 8. ed. São Paulo: Saraiva, 2003.

MESQUITA, Manoel Henrique. Obrigações reais e ônus reais. Coimbra: Almedina, 2000.

PEREIRA, Gaio Mário da Silva. Responsabilidade civil. 8. ed. Rio de Janeiro: Forense,1996.

TORRES, Marcos Alcino de Azevedo. A propriedade ea posse. Rio de Janeiro: Lúmen Juris, 2008.

VENOSA, Sílvio de Salvo. Direito Civil. v. 4. 3. ed. São Paulo: Atlas, 2003.

Alei do inquilinato. 8. ed. São Paulo: Atlas, 2007.

\section{RENTAL CONTRACTSAND CIVIL LIABILITY}

Abstract: The article deals with civil liability arising from the tenant's failure to comply with his/her obligations before the landlord in a urban property rental relationship. This article intends to classify the kind of liability that must be considered and to analyse theprimary and accessory obligations that must be observed by the tenant, whose default generates a right to compensation.

Keywords: Contract. Civil liability. Real estate. Rental of urban property. 